\title{
How do the Ordinary People Invest Chinese A Share?
}

\author{
Evidence from residents of Mid-town district in Xiaoshan, China
}

\author{
Liang Renfang \\ School of Finance \\ Zhejiang University of Finance and Economics, \\ Hangzhou, China
}

\author{
$\mathrm{He} \mathrm{Yu} *$ \\ School of Finance \\ Zhejiang University of Finance and Economics, \\ Hangzhou, China \\ E-mail:heyu1021@live.com \\ * Corresponding Author
}

\author{
Wang Junqiao \\ School of Finance \\ Zhejiang University of Finance and Economics, \\ Hangzhou, China
}

\begin{abstract}
To investigate the investment behavior in the Chinese stock market, 2,000 residents of the mid-scaled town of Xiaoshan completed a survey questionnaire. Sample survey and typical survey results show that most stock investors are young persons with relatively low education background. They use idle funds to invest and exhibit strong Herd effects as they usually act collectively without centralized direction. Another obvious behavior character is that they tend to sell profitable stocks while hold passive stocks, which is highly consistent with disposition effect. The data collected and the analysis in this paper is beneficial to study investors trading behavior as well as psychological ownership. It can also to a large extent explain Chinese stock market performance.
\end{abstract}

Keywords-Chinese Urban Residents; Stock Exchange; Behavioral Finance; Herding Effect; Disposition Effect.

\section{INTRODUCTION}

Shanghai stock exchange composite index, the most prominent standard of Chinese stock market, rushes up to 5000 points and come back to 2,850 points in a 6 monthly period. This fluctuate cycle allows investors gain an average $43 \%$ yield at May, 2015. Conversely, in the week of June 12 th to 19 th 2015 a loss of $¥ 100,000^{1}$ was experienced in which Chinese investors played an important role. Research on the traits of individual Chinese investors can help increase awareness of poor strategies that will reduce unnecessary loss and provide benefits for investment decisions from foreign investors.

From the second half of 2014 to May 2015, A-share ushered in a new round of rising prices and make a new index, which rushes to 5000 points and make investors get average yield of $43 \%{ }^{2}$ Then since in June, the index fell

\footnotetext{
${ }^{1}$ http://economy.gmw.cn/newspaper/2015/06/23/content_107439 247.htm
}

${ }^{2}$ http://www.wj001.com/news/cjzq/2015-06-19/667151.html from 5000 points to 2850 points and the capita loss of investors attain over $¥ 100,000^{3}$. The investors have experienced the ups and downs of stock in half a year and acquire a profound lesson. Therefore, on the one hand, acknowledging investors stocks situation is particularly beneficial to help investors find the weaknesses of their own transactions in the stock market's floating and reduce suffering enormous losses; on the other hand, the investors abroad tends to make A-share investment based on Ashare investors Transactions.

\section{LITERATURE}

Since the 1980s, some financial experts learn discipline theoretical achievements of psychology, sociology, behavioral science to analyze the behavior of investors, which mainly starts from the actual state mind and investment behavior of investors .For example, Shefrin and Statman (1985) [1] thinks investors regret to walk free, in fact, tend to continue to hold the deficit stock had lost and the price has been eager to cash after rising stock (the "Disposition effect"); Barberis (2001) [2]finds that most of the loss of investment staff generally is overconfident, that personally think that an event will definitely take place, in fact, is not the probability, so often these investments in the stock market will be frequent trading; Bikhchandani and Sharma(2001)[3] shows that "Herding effect" is very widespread in the stock market, although the market will aggravate instability, but inevitable; Besides, Lim (2006)[4], Jr, Mineto and Silver (2008)[5], Lee et.al (2008)[6] demonstrates that Disposition effect is widespread in the stock market.

Chinese stock market develops rapidly in the past few years and many research has been done on the behavior of Chinese market investors. Peiyuan Sun (2002) [7], Tan

${ }^{3}$ http://economy.gmw.cn/newspaper/2015/06/23/content_107439 247.htm 
et.al (2008) [8], Chiang et.al (2010) [9] found that Chinese stock market presents highly herding effect. Yulei Rao (2003) [10] systematically demonstrated investors' overconfidence and emotional bias in China. Xindan Li et.al (2005) [11] illustrated Chinese stock market investors' above irrational behavior according to individual investors' survey and stock market trading data. Yuan Li and Jie Li (2013)[12] summarize individual investors' trading behavior based on psychology and found that most stock investors in Chinese stock market trade too frequently and rely too much private information, gamble with policies, exhibit obvious disposition effect.

However, most of the survey data these research based on are collected ten years ago. Chinese A-share market has developed for more than 20 years and many new traits have been appeared, so it is essential to update new data and analysis investors' behavior. This paper investigates urban residents' trading behavior in a Mid-sized town Xiaoshan, and analysis their trading defects of most investors.

Overall, the current results show that equity investors generally have overconfidence, herding and disposition effect and other irrational behavior. For example, investors overestimate their ability to control risk and underestimate the risk of the stock market. Consequently, people always think their own trading behavior is absolutely correct to result in frequent trading; most investors invest in listed companies not based on fundamental data but based on some "inside information" and the national policy news, plus some securities practitioners encouraged stock investors to follow the trend to trade; at the same time, many investors cannot effectively analyze future trends stock market and tends to continue to hold a loss of stock, eager to cash in the rising stock. Notably particularly, most researches are rather older and the survey data has been about a decade. Though the A-share has been experienced more than 20 years of development, it is now lack of appropriate statistical survey about investment situation. So this paper investigates the stock trading situation in Mid-town district in Xiaoshan, China and analysis defect of investment existed in the area of urban residents for the results of research.

\section{QUESTIONNAIRES}

This study carries on a survey on a Midsized town Xiaoshan by sample survey and typical survey. The investigation subjects include community residents, businessman around the community, the banking staff et al. Basic information contains gender, age, education background, income and occupation. Some questions about investment basis, fund source, investment position, investment return, ownership mentality and trend prediction are also included.

Investment situation. We also designed some questions about investment basis, capital source, investment position, investment result, ownership mentality and views on the stock market trend. From the investment purpose we can learn the motivation of residents' A share investment. And from their risk awareness, we can get the conclusion whether the trading behavior of residents is rational or not.

\section{RESPONDENT ANALYSIS}

In August, 2015, 2,000 questionnaires have been randomly send out to community residents, businessman around the community, the banking staff et al. Eventually, there were 1640 effective respondents, involving 680 residents who invested in A share and 960 residents who don't. The basic situation of respondent is shown in table I.

\section{A. The Basic Situation of Residents' Investors.}

From the questionnaires, the proportion of resident investors are not big, only less than fifty percent residents invest A share stocks. Most of them are teenager and their education background are mainly college level. Besides, their monthly incomes are generally between $¥ 4,000$ and $¥ 6,000$, just meeting basic daily requirements and the left investing in the stock market.

TABLE I. THE BASIC SITUATION OF COLLEGE STUDENT INVESTORS

\begin{tabular}{|c|c|c|}
\hline Items & Results & Percentage $(\%)$ \\
\hline \multirow{3}{*}{ Gender } & Male & 52.4 \\
\hline & & \\
\hline & Female & 47.6 \\
\hline \multirow{3}{*}{ Age } & $18-35$ & 61.3 \\
\hline & $36-60$ & 35.0 \\
\hline & More than 60 & 3.7 \\
\hline \multirow{4}{*}{ Education } & Junior high school graduate & 6.1 \\
\hline & High School graduate & 23.2 \\
\hline & College undergraduate & 67.1 \\
\hline & Postgraduate & 3.7 \\
\hline \multirow{4}{*}{ Income } & Less than $¥ 4000$ & 25.4 \\
\hline & $¥ 4000$ - ¥6000 & 41.9 \\
\hline & $¥ 6000$ - ¥10000 & 27.8 \\
\hline & More than $¥ 1000$ & 4.9 \\
\hline \multirow{5}{*}{ Profession } & Student & 9.4 \\
\hline & Company staff & 26.7 \\
\hline & Finance-related professionals & 35.2 \\
\hline & Freelance & 22.4 \\
\hline & Retirement & 6.1 \\
\hline
\end{tabular}

\section{B. Fund Sources}

Individual investors' money primarily come from their deficit above daily expenditure. Corresponding to 
the results of table II, the survey result is not difficult to find that financial management of the city residents mid-scaled district in Xiaoshan are the traditional deposits accounted for $30 \%$, financial products taken another $30 \%$ and stocks contributed to 28 percent .

TABLE II. THE APPLICATION OF IDLE FUNDS

\begin{tabular}{|c|c|}
\hline Application & percentage (\%) \\
\hline Own saving & 30 \\
\hline Bonds invest & 7 \\
\hline Bank money & 30 \\
\hline Stocks & 28 \\
\hline Others & 5 \\
\hline
\end{tabular}

V. SURVEY RESUlTS

\section{A. Stock Selection}

From the table III, when selecting stocks, some residents investors analyze by themselves or follow others, choices, such as stock recommendation of securities analysts, or recommendations of friends, which accounts for $69 \%$. However, approximately $31 \%$ of people analyze the stock from the corner of technology analysis and value analysis.

TABLE III. STOCK SELECTION

\begin{tabular}{|c|c|}
\hline Trading reason & Percentage \% \\
\hline Recommendation from securities analysts or friedns & 37 \\
\hline Their own analysis & 32 \\
\hline Value analysis & 23 \\
\hline Technology analysis & 8 \\
\hline
\end{tabular}

\section{B. Proportion of Household Assets.}

Most investors spend less than $10 \%$ of the total household assets on stocks, while only 3\% employ more than $50 \%$ of their assets on stock markets. It shows that Chinese urban residents are relatively conservative and inclined to distribute their money on safer assets.

From the capital data of funds accounted for the proportion of total household assets (Table IV), most of stock funds accounts for $10 \%$ and below in total household assets. Most urban residents are savings-based in traditional way of managing money.
TABLE IV. FUNDS ACCOUNTED FOR THE PROPORTION OF TOTAL HOUSEHOLD ASSETS

\begin{tabular}{|c|c|}
\hline Proportion of total household assets & Percentage $\%$ \\
\hline Less than $10 \%$ & 66 \\
\hline $10 \%-30 \%$ & 28 \\
\hline $30 \%-50 \%$ & 3 \\
\hline More than $50 \%$ & 3 \\
\hline
\end{tabular}

\section{Earnings}

Obviously, about $20 \%$ of resident investors gain profit, whilst most investors loss money (see Table V). However, from the second half of 2014 to May 2015, A-share make investors get average yield of $43 \%$. Actually, a few investors get great loss when the A-share index rush from 5000 points.

TABLE V. EARNING

\begin{tabular}{|c|c|}
\hline Earning & Percentage \% \\
\hline Profit & 20 \\
\hline Loss & 28 \\
\hline Fair & 33 \\
\hline Hard to say & 19 \\
\hline
\end{tabular}

\section{Investment Mentality.}

When the A-share index rushes, about $30 \%$ of resident investors hold a view that stock fluctuation has not affected their determination, while more than $27 \%$ believe that it has a certain influence and makes stock sale; there are more than $40 \%$ resident investors even hardly take action to make up to their loss (Fig .1).

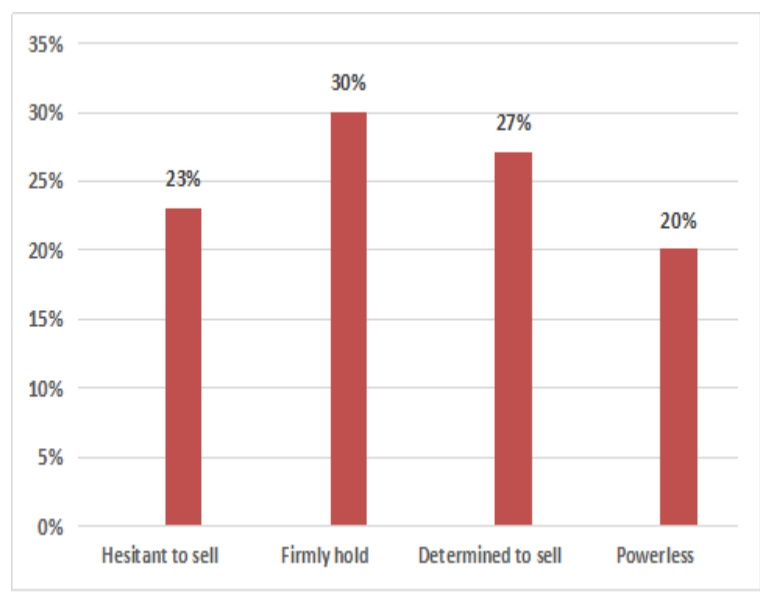

Figure 1. Investment Mentality

E. Attitude toward Holding Stock and Futures of Stock.

After the A-share index rushes, approximately $37 \%$ of residential investors shows that stock fluctuation ought to make a longer duration while $35 \%$ of residents investors demonstrates that stock fluctuation is unpredictable. What's more, about $24 \%$ of them still firmly believe that 
A-share index will be back in the near future. Surprisingly, only $4 \%$ of them show pessimistic to A-share (Fig.2).

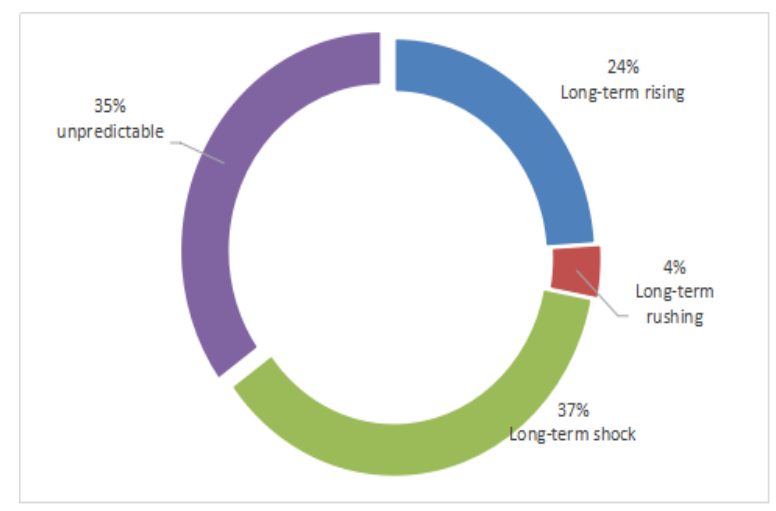

Figure 2. Attitude toward Holding Stock and Futures of Stock.

\section{CONCLUSION}

\section{A. Most of Resident Investors are Teenager and their Level of Education is Mainly College. What's More, their Funds Mainly Come From Their Idle Funds.}

Most of their investors in Mid-scaled district in Xiaoshan, China are teenager and their level of education is mainly college undergraduate. Besides, some of them work in finance-related industries(Table I) and their funds mainly come from their idle funds, which accounts for $10 \%$ and below in total household assets. Most urban residents are savings-based in traditional way of managing money(Table II).

\section{B. Herd Behavior}

According to statistical data from the survey, when selecting stocks, $69 \%$ of residents investors analyze by themselves or follow others' choices, such as stock recommendation of securities analysts, or recommendations of friends. While approximately $31 \%$ of people analyze the stock from the corner of technology analyses and value analyses(Table III).It is also verified (as shown in Table I) that education of most stock investment staffs is not high.

\section{Disposition Effect}

It is notable that about $53 \%$ of resident investors do not get objectively income(Table V) while $28 \%$ of resident investors get loss .However, from the second half of 2014 to May 2015, A-share make investors get average yield of $43 \%$. Actually, a few investors tend to sell profitable stocks and continue to hold the loss stock in unfavorable situation.

\section{Passive Holding Stock}

After the A-share index rushes, about $30 \%$ of resident investors still think that stock fluctuation has not affected their determination while approximately $27 \%$ of people are hesitant whether it is time to sell stock, at the same time, $20 \%$ of investors show powerless to stock. But only $27 \%$ of investors surely demonstrates that it has a certain influence and makes stock sale(Fig.1). Actually, about $24 \%$ of them still firmly believe that A-share index will be back in the near future, approximately $37 \%$ of residential investors shows that stock fluctuation ought to make a longer duration while $35 \%$ of residents investors demonstrates that stock fluctuation is unpredictable. Surprisingly, only $4 \%$ of them shows than the A-share will rush again (Fig.2). It should be noted that the government has a high degree of confidence from investors, $30 \%$ of investors believe the action of government is certainly successful and resolutely holds stock.

\section{ACKNOWLEDGMENT}

This paper is sponsored by Zhejiang Provincial Natural Science Foundation (No. LY14G030013).

\section{REFERENCES}

[1] Shefrin H, Statman H M. The disposition to sell winners too early and ride losers too long: Theory and evidence[J]. Journal of Finance, 1985, (40):777-791.

[2] Barberis, Nicholas, Ming Huang, Tano Santos. Prospect Theory and Asset Prices, forthcoming, Quarterly Journal of Economics[M] 2001 .

[3] ]Bikhchandani S, Sharma S. Herd Behavior in Financial Market[J] IMF Staff Papper, 2001, 47:279-310.

[4] Lim S S. Do investors integrate losses and segregate gains? Metal ac;c;ounting and investor trading decisions $[\mathrm{J}]$. Journal of Business, 2006, 79(5):2539-2573.

[5] Jr N D, Mineto C, Silver S D. Disposition effect and gender[J] . Applied Economic Letters, 2008, (15):411-416.

[6] Lee H J, Park J, Lee J Y. Disposition effects and underlying mechanisms in e-trading of stocks [J]. Journal of Marketing Research, 2008, (7):362-378.

[7] Sun Pei-yuan, Shi Dong-hui.CAPM Based Study of Herd Behavior: Evidence from Chinese Stock Market and Discussion with Song Jun and Wu Chongfent[J].Economic Research Journal,2002,02:64$70+94$.

[8] Tan L, Chiang T C, Mason J R, Nelling E. Herding Behavior in Chinese Stock Market: An Examination of A and B shares[J]. Pacific-Basin Finance Journal, 2008, 16:61-77.

[9] Chiang T C, Li J D, Tan L. Empirical Investigation of Herbing Behavior in Chinese Stock Markets: Evidence from Quantile Regression Analysis[J]. Gold Finance Journal, 2010,21:111-124.

[10] Rao Yu-lei. The Meanangs and Prospects of Behavior Finance[J]. Management Review, 2003, 05:26-29+63.

[11] Li Xin-dan. The Construction and Prospects of Behavior Finance[J]. Journal of Financial Research, 2005,01:175-190.

[12] Li Yuan, Li Jie. The Analysis and Suggestion about Investment based on Behavior Finance in stock market[J]. Finance \& Economy,2013,24:91-92. 